\title{
PENGARUH PUPUK NPK MUTIARA DAN PUPUK PLANT CATALYST TERHADAP PERTUMBUHAN DAN HASIL TANAMAN CABAI MERAH KERITING (Capsicum annuum L.) VARIETAS LADO F1
}

\author{
Dedi Purwanto ${ }^{1}$ \\ ${ }^{1}$ Agroteknologihutanan, Fakultas Pertanian, Universitas 17 Agustus 1945 Samarinda, \\ Indonesia. \\ E-Mail: dedi89@gmail.com
}

\begin{abstract}
ABSTRAK
Pengaruh Pupuk NPK Mutiara dan Pupuk Plant Catalyst terhadap Pertumbuhan dan Hasil Tanaman Cabai Keriting (Capsicum annuumL.) Varietas Lado F1. Tujuan penelitian adalah untuk : (1) mengetahui pengaruh pemberian pupuk NPK Mutiara dan pupuk Plant Catalyst serta interaksinya terhadap pertumbuhan dan hasil tanaman cabai keriting varietas Lado F1; dan (2) memperoleh dosis pupuk NPK Mutiara dan konsentrasi pupuk Plant Catalyst yang sesuai untuk pertumbuhan dan hasil tanamam cabai keriting, sehingga diperoleh hasil yang tinggi.

Penelitian menggunakan percobaan faktorial 4 x 4 dalam Rancangan Acak Lengkap (RAL) yang diulang sebanyak5 kali. Faktor pertama adalah dosis pupuk NPK Mutiara (M) yang terdiri atas4 taraf : tanpa pupuk NPK Mutiara $(\mathrm{m} 0)$, 1g polibag ${ }^{-1}(\mathrm{~m} 1)$. 1,5 $\mathrm{g}$ polibag $^{-1}(\mathrm{~m} 2)$; dan $2 \mathrm{~g}_{\text {polibag }}{ }^{-1}(\mathrm{~m} 3)$. Faktor kedua adalah konsentrasi pupuk Plant Catalyst (P) terdiri atas 4 taraf :tanpa pupuk Plant Catalyst (p0), $1 \mathrm{~g} \mathrm{l}^{-1}$ air (p1), 1,5g $\mathrm{I}^{-1}$ air (p2), dan $2 \mathrm{~g}^{-1}$ air (p3).

Hasil penelitian menunjukkan bahwa : (1) perlakuan pupuk NPK Mutiara berpengaruh sangat nyata dan nyata terhadap tinggi tanaman pada umur 2 dan 6 minggu setelah tanam, tetapi berpengaruh tidak nyata terhadap tinggi tanaman pada umur 4 minggu setelah tanam, umur tanaman saat berbunga, umur tanaman saat panen, jumlah buah dan berat buah per tanaman; (2) perlakuan pupuk Plant Catalyst berpengaruh sangat nyata terhadap tinggi tanaman pada umur 2 minggu setelah tanam, tetapi berpengaruh tidak nyata tinggi tanaman pada umur 4 dan 6 minggu setelah tanam, umur tanaman saat berbunga, umur tanaman saat panen, jumlah buah dan berat buah per tanaman; (3) interaksi antara perlakuan dosis pupuk NPK Mutiara dan perlakuan konsentrasi pupuk Plant Catalyst berpengaruh nyata terhadap tinggi tanaman pada umur 2 minggu setelah tanam, tetapi berpengaruh tidak nyata tinggi tanaman pada umur 4 dan 6 minggu setelah tanam.
\end{abstract}

Kata kunci : Cabai Keriting, Pertumbuhan, Pupuk NPK Mutiara, Pupuk Plant Catalyst.

\begin{abstract}
Effect of NPK Mutiara Fertilizer and Plant Catalyst Liquid Fertilizer on the Growth and Yield of Red Pepper(Capsicum annuum L.) Lado F1 Variety. The research objective were to study the effect of NPK Mutiara fertilizer and Plant Catalyst liquid organic fertilizer and its interaction on the growth and yield of red pepper and also to find the proper dosage of NPK Mutiara fertilizer and Plant Catalyst liquid fertilizer concentration for obtaining the best growth and yieldof red pepper.

The research used Completely Randomized Design (CRD) in $4 \times 4$ Factorial Experiment and five replications. The factor was the dosage of NPK Mutiara fertilizer $(M)$ consisting of 4 levels : no NPK Mutiara fertilizer application $(\mathrm{m} 0) ; 1 \mathrm{~g}$ polybag ${ }^{-1}(\mathrm{~m} 1) ; 1,5 \mathrm{~g} \mathrm{polybag}^{-1}(\mathrm{~m} 2)$; and $2 \mathrm{~g}$ polybag $^{-1}(\mathrm{~m} 3)$. The second factor was the concentration of Plant Catalyst liquid fertilizer $(P)$ consisting 4 levels : no Plant Catalyst liquid fertilizer application ( $p 0) ; 1 \mathrm{~g} l^{-1}$ water (p1);1,5 $\mathrm{gl}^{-1}$ water ( 2 2), and $2 \mathrm{~g} l^{-1}$ water ( $\mathrm{p} 3$ ).

The results of the reasearch showed that: (1) the NPK Mutiara fertilizer treatment affected significantly to very significantly on theplant lenght at age 2 and 6weeks days after planting, but it did not affect significantly on theplant lenght at age 4weeks after planting, age of plants flowered, age of plant harvested, number of fruit and fruit weight per plant; (2) the Plant Catalyst liquid fertilizer treatment affected very significantly on theplant lenght at age 2 weeks days after planting, but it did not affect significantly on theplant lenght at age 4 and 6 weeks after planting, age of plants flowered, age of plant harvested, number of fruit and fruit weight
\end{abstract}


per plant; (3) the interaction treatment between NPK Mutiara and Plant Catalyst liquid fertilizer affected significantly on the plant lenght at age 2 weeks after planting, but did not affect significantly on the plant lenght at age 4 and 6 weeks after planting.

Key words : Catalyst Plant Fertilizer, Curly Chili, Growth, NPK Mutiara Fertilizer.

\section{PENDAHULUAN}

Cabai keriting (Capsicum annuum L.) merupakan salah satu jenis sayuran penting di Indonesia. Selain memiliki nilai gizi yang cukup tinggi, cabai juga memiliki nilai ekonomi yang tinggi. Pemanfaatan cabai sebagai bumbu masak, sebagai bahan baku berbagai industri makanan, minuman dan obatobatan membuat cabai semakin menarik untuk diusahakan. Produksi cabai nasional yang masih rendah seringkali membuat pasokan cabai dipasaran terbatas. Pasokan cabai yang terbatas berakibat terjadinya fluktuasi harga yang besar. Perbaikan terhadap sistem produksi cabai merupakan salah satu cara untuk meningkatkan produksi cabai. Peningkatan produksi cabai akan menjaga pasokan cabai di pasar tetap stabil sehingga fluktuasi harga dapat ditekan.

Berdasarkan deskripsi botanisnya, tanaman cabai memiliki potensi produktivitas hingga 20 tonha $^{-1}$. Namun, fakta di lapangan menunjukkan bahwa produksi cabai rata-rata jauh dari potensi produksinya. Pada tahun 2012, produksi cabai di Indonesia hanya mencapai 1.656.615 ton dari luas panen yang mencapai 242.366 hektar. Jumlah tersebut menunjukkan bahwa produktivitas tanaman cabai nasional hanya mencapai 6,84 tonha $^{-1}$. Sementara itu, produksi rata-rata cabai di Provinsi Kalimantan Timur pada tahun 2011, 2012, 2013, 2014 dan 2015 berturu-turut hanya mencapai 3,$64 ; 3,82 ; 4,44 ; 5,60$, dan 5,42 ton ha ${ }^{-1}$ (BPS Provinsi Kaltim, 2015).

Salah satu faktor yang mempengaruhi produksi cabai nasional adalah kondisi tanah yang kurang subur akibat digunakan secara terus-menerus. Tindakan budidaya yang tepat diperlukan untuk mendapatkan produksi tanaman yang tinggi pada tanah yang kurang subur tersebut. Salah satu tindakan yang dapat dilakukan adalah dengan cara melakukan pemupukan. Pupuk merupakan bahan yang mendukung kesuburan tanah karena berisi satu atau lebih unsur untuk menggantikan unsur yang telah diabsorsi oleh tanaman (Lingga dan Marsono, 2013). Tanaman cabai termasuk tanaman yang memerlukan unsur hara $\mathrm{N}, \mathrm{P}$, dan $\mathrm{K}$ dalam jumlah yang relatif banyak. Oleh karena itu, untuk mendapatkan produksi yang maksimal, tanaman cabai harus diberi asupan unsur hara yang optimal.

Pemupukan merupakan salah satu kunci utama keberhasilan peningkatan produksi cabai di Indonesia. Dampak pemupukan yang efektif akan terlihat pada pertumbuhan tanaman yang optimal dan produksi yang meningkat dengan signifikan. Unsur hara $\mathrm{N}, \mathrm{P}$, dan $\mathrm{K}$ merupakan unsur hara makro yang sangat dibutuhkan bagi tanaman cabai. Menurut Hasibuan (2004), unsur hara N, P, dan K didalam tanah umumnya tidak cukup untuk menunjang pertumbuhan tanaman. Hal ini karena unsur hara di dalam tanah terus-menerus diserap untuk pertumbuhan tanaman. Sementara itu, penambahan unsur hara dari hasil dekomposisi bahan organik tidak memadai. Selain itu, unsur hara di dalam tanah juga mengalami proses pencucian, penguapan, dan tererosi sehingga membuat ketersediaan unsur hara semakin berkurang.

Saat ini, di pasaran telah beredar berbagai jenis pupuk baik yang organik maupun non organik. Salah satu pupuk yang dapat digunakan untuk memenuhi 
kebutuhan unsur hara pada budidaya cabai adalah pupuk NPK Mutiara (16:16:16). Pupuk NPK Mutiara adalah pupuk majemuk yang mengandung tiga unsur hara utama yang dibutuhkan tanaman, yaitu $\mathrm{N}$, $\mathrm{P}$, dan $\mathrm{K}$ dengan perbandingan unsur 16:16:16. Pemberian pupuk NPK Mutiara ke dalam tanah dalam jumlah yang optimal akan mendukung peningkatan hasil panen pada budidaya tanaman cabai. Menurut Novizan (2007), tujuan pemberian pupuk ke dalam tanah adalah untuk menggantikan unsur hara yang telah diserap oleh tanaman dan hilang akibat pencucian sehingga unsur hara dalam tanah tetap tersedia.

Pemupukan NPK pada lahan pertanian seringkali kurang efektif. Hal ini disebabkan unsur hara di dalam pupuk terikat oleh koloid tanah sehingga tidak tersedia bagi tanaman. Oleh sebab itu, perlu ada solusi untuk meningkatkan efektifitas penggunaan pupuk pada lahan pertanian. Salah satu cara yang dapat dilakukan untuk meningkatkan efektivitas penggunaan pupuk NPK adalah dengan mengkombinasikannya dengan pupuk daun.

Plant Catalyst merupakan pupuk pelengkap yang mengandung unsur hara makro dan mikro serta dapat menjadi katalisator untuk mengoptimalkan penyerapan pupuk-pupuk utama pada media tanam dan pupuk dasar. Plant Catalyst berfungsi meningkatkan kemampuan tanaman menyerap unsur hara dari berbagai pupuk utama seperti Urea, TSP, KCL, Za, maupun pupuk alami, seperti pupuk kandang, kompos, dan lain-lain sehingga tanaman dapat mencapai produktivitas yang optimal (CNI, 2011). Plant Catalyst merupakan pupuk pelengkap yang mengandung unsur hara makro dan mikro serta dapat menjadi katalisator untuk mengoptimalkan penyerapan pupukpupuk utama pada media tanam dan pupuk dasar. Konsenterasi Plant Catalyst $1,5 \mathrm{~g} \mathrm{l}^{-1}$ air mampu meningkatkan potensi hasil tanaman sawi dibandingkan dengan konsentrasi 2-3 $\mathrm{g} \mathrm{l}^{-1}$ air, pada konsentrasi tersebut terjadi peningkatan berat segar tanaman melalui lebar daun dan tinggi tanaman.

Berdasarkan uraian di atas, maka dilakukan penelitian mengenai pengaruh pupuk NPK Mutiara dan pupuk Plant Catalyst serta interaksinya terhadap pertumbuhan dan hasil tanaman cabai keriting varietas Lado F1. Tujuan Penelitian adalah untuk mengetahui pengaruh pupuk NPK Mutiara dan pupuk Plant Catalyst serta interaksinya terhadap pertumbuhan dan hasil tanaman cabai keriting (Capsicum annuum L) Variatas Lado F1. Untuk menemukan dosis pupuk NPK Mutiara dan konsentrasi pupuk Plant Catalyst yang sesuai untuk hasil tanaman cabai keriting(Capsicum annuиm L) Variatas Lado F1.

\section{METODA PENELITIAN}

\subsection{Tempat dan Waktu}

Lokasi penelitian di Desa Bukit Raya Kecamatan Tenggarong Seberang, Kutai Kartanegara. Pada bulan MeiSeptember 2018.

\subsection{Bahan dan Alat}

Bahan yang digunakan dalam penelitian ini yaitu : benih cabai keriting varietas Lado F1, pupuk NPK mutiara, pupuk Plant Catalyst, polibag ukuran $50 \mathrm{~cm} \mathrm{x} 40 \mathrm{~cm}$, Regent 50 EC, dan air.

Alat yang digunakan dalam penelitian ini adalah polibag, cangkul, ajir bambu, plastik naungan, penyaring tanah, ember, nampan, penggaris, meteran, timbangan analitik, hand sprayer, dan alat tulis.

\subsection{Rancangan Penelitian}

Penelitian mengggunakan Percobaan Faktorial 4 x $4 \quad 4$ dalam 
Rancangan Acak Lengkap (RAL). Adapun faktor-faktor perlakuan yaitu :

Faktor pertama yaitu dosis pupuk NPK Mutiara (M) terdiri atas 4 taraf yaitu:

$$
\begin{aligned}
& \mathrm{m} 0=\text { tanpa pupuk NPK Mutiara } \\
& \mathrm{m} 1=1 \mathrm{~g} \mathrm{polibag}^{-1} \\
& \mathrm{~m} 2=1,5 \mathrm{~g} \mathrm{polibag}^{-1} \\
& \mathrm{~m} 3=2 \mathrm{~g} \mathrm{polibag}^{-1}
\end{aligned}
$$

Faktor kedua adalah konsentrasi pupuk Plant Catalyst (P) terdiri atas 4 taraf, yaitu:

p0 $=$ tanpa pupuk Plant Catalyst

$\mathrm{p} 1=1 \mathrm{gl}^{-1}$ air

p2 $=1,5 \mathrm{~g}^{-1}$ air

p3 $=2 \mathrm{~g}^{-1}$ air

secara keseluruhan terdapat 16 kombinasi perlakuan, dan setiap kombinasi perlakuan diulang sebanyak 5 kali, sehingga terdapat 80 unit penelitian, yaitu :

$\begin{array}{ll}\text { m0p0 } & \text { m0p1 } \\ \text { m0p2 } & \text { m0p3 } \\ \text { m1p0 } & \text { m1p1 } \\ \text { m1p2 } & \text { m1p3 } \\ \text { m2p0 } & \text { m2p1 } \\ \text { m2p2 } & \text { m2p3 } \\ \text { m3p0 } & \text { m3p1 } \\ \text { m3p2 } & \text { m3p3 }\end{array}$

\subsection{Pelaksanaan Penelitian}

\section{Penyemaian benih}

Benih dilakukan perendaman dalam air hangat terlebih dahulu selama 2 jam, setelah direndam benih ditiriskan dan dikeringanginkan. Benih yang telah dikeringanginkan terlebih dahulu dilakukan pendedaran pada nampang plastik. Bak semaian yang digunakan yaitu berupa nampan yang berlubang pada bagian bawah dan ke empat sisi nampan. Wadah tersebut diisi media campuran tanah bakaran sampai dengan ketebalan $\pm 3 \mathrm{~cm}$. Benih cabai disebarkan secara merata pada media semai lalu ditutup tipis dengan media setebal 0,5 $\mathrm{cm}$. Persemaian disiram dengan cara menambahkan air ke dalam tatakan untuk meminimalisir terjadinya limpasan pada saat penyiraman. Setelah benih cabai memiliki 4 daun dan tingginya $\pm 10 \mathrm{~cm}$ siap dipindahkan ke polibag.

Penyiapan media tanam

Tanah yang akan dijadikan media tanam untuk penelitian berasal dari tanah lapisan atas dengan kedalamaan 0-20 cm yang ada di sekitar penelitian. Tanah dicangkul beberapa kali hingga bongkahan tanah hancur dan gembur, kemudian tanah dibersihkan dari gulma dan dikeringanginkan selama 1 hari. Tanah dimasukkan ke polibag ukuran 50 $\mathrm{cm}$ x $40 \mathrm{~cm}$ sebanyak $20 \mathrm{~kg}$, setelah polibag tersebut diberi label perlakuan/ulangan dan disusun rapi dengan jarak $60 \quad \mathrm{~cm} \quad \mathrm{x} \quad 60 \mathrm{~cm}$ sesuaidengan hasil acak sederhana dengan menggunakan undian.

\section{Pemberian pupuk NPK Mutiara}

Pemberian pupuk NPK Mutiara diberikan satu kali pada setiap polibag disesuaikan dengan perlakuan, yaitu : tanpa pupuk NPK Mutiara (m0), $1 \mathrm{~g}$ polibag $^{-1}(\mathrm{~m} 1)$, 1,5 $\mathrm{g}_{\text {polibag }}{ }^{-1}(\mathrm{~m} 2)$, dan 2 g polibag $^{-1}(\mathrm{~m} 3)$. Pupuk NPK Mutiara diberikan sekaligus pada saat tanam dengan cara menebarkan diatas media tanam lalu dicampurkan dengan media tanam.

\section{Penanaman}

Sebelum dilakukan penanaman, media tanam dibuat lubang tanam di tengah polibag sedalam $5 \mathrm{~cm}$, lalu bibit diambil dari persemaian dengan hati-hati dan ditanam pada lubang tanam pada setiap polibag, lalu timbun dengan media tanam hingga $1 \mathrm{~cm}$ di atas pangkal batang dan media tanam disiram dengan air hingga lembab.

\section{Pemberian pupuk Plant Catalyst}

Pemberian pupuk Plant Catalyst pada setiap polibag disesuaikan dengan perlakuan, yaitu : tanpa pupuk Plant 
Catalyst (p0), $1 \mathrm{gl}^{-1}$ air (p1), 1,5 $\mathrm{gl}^{-1}$ (p2), dan $2 \mathrm{gl}^{-1}$ air (p3). Pupuk Plant Catalyst diaplikasikan pada tanaman dengan cara disempotkan pada tanaman terutama pada bagian daun sebelah bawah pada sore hari $\begin{array}{llll}\text { antara } & 16.00-17.00 \quad \text { Wita. }\end{array}$ Penyemprotan dilakukan pada umur 2, 4 dan 6 minggu setelah tanam.

\section{Pemeliharaan}

Pemeliharaan tanaman meliputi: Penyiraman tanaman disiram dilakukan 2 kali sehari (pagi atau sore hari) bila media masih terlihat lembab atau turun hujan maka dilakukan penyiraman. Pengajiran dilakukan setelah tanaman berumur 3 minggu setelah tanam dengan menggunakan bambu. Pembuangan tunas air (tunas liar) yang dilakukan setelah tanaman berumur 3 minggu. Pengendalian semut dengan menyemprotkan larutan Regent 50 EC dengan konsentrasi $1 \mathrm{ml} \mathrm{l}^{-1}$ air yang dilakukan pada saat tanaman berumur 3 dan 4 minggu setelah tanam.

\section{Panen}

Panen buah cabai keriting dilakukan apabila warna buah sudah berubah dari warna hijau menjadi merah. Panen dilakukan 5 kali secara bertahap sesuai dengan tingkat kemasakan. Waktu panen dilakukanpada pagi atau sore hari dengan interval waktu 3 hari.

\subsection{Pengambilan Data}

Data utama

a. Tinggi tanaman diukur dari pangkal batang tanaman $2 \mathrm{~cm}$ di atas permukaan tanah (diberi tanda) hingga ke titik tumbuh tertinggi. Pengukuran tinggi dilakukan pada umur 2, 4, dan 6 minggu setelah tanam $(\mathrm{cm})$.

b. Umur tanaman saat berbunga diamati dengan menghitung jumlah hari sejak dari tanam sampai tanaman mengeluarkan bunga pertamakali (hari setelah tanam).

c. Umur tanaman saat panen diamati dengan menghitung jumlah hari sejak dari tanam sampai tanaman dipanen pertamakali (hari setelah tanam).

d. Jumlah buah per tanaman diamati dengan menghitung buah hasil panen pertama sampai buah hasil panen kelima kemudian dijumlahkan (buah).

e. Berat segar buah per tanaman diamati dengan menimbang berat buah hasil penen pertama sampai panen kelima kemudian dijumlahkan (kg tanaman-1).

Data penunjang

Data penunjang adalah analisis tanah di laboratorium tanah Fakultas Pertanian Universitas Mulawarman Samarinda dan data curah hujan dari UPTD Pertanian Tenggarong Seberang.

\subsection{Analisis Data}

Untuk mengetahui pengaruh pupuk NPK Mutiara dan pupuk Plant Catalyst serta interaksinya terhadap pertumbuhan tanaman cabai keriting dilakukan dengan sidik ragam. Model sidik ragam yang digunakan menurut Steel dan Torrie (1991).

Bila dari hasil sidik ragam menunjukkan berbeda nyata (F hitung $>\mathrm{F}$ tabel 5\%) dan berbeda sangat nyata (F hitung > F tabel 1\%), maka untuk membandingkan dua rata-rata perlakuan dilakukan uji lanjutan dengan Beda Nyata Terkecil (BNT) pada taraf 5\%. Sedangkan bila hasil sidik ragam berbeda tidak nyata ( $F$ hitung $\leq \mathrm{F}$ tabel $5 \%$ ) tidak dilakukan uji lanjutan. Rumus umum uji BNT adalah : 


$$
\text { BNT } 5 \%=\mathrm{t} \text { tabel } \mathrm{x} \sqrt{\frac{2 \text { KTgalat }}{r x t}}
$$

Keterangan :

$$
\begin{array}{ll}
\mathrm{t}-\text { tabel } & =\text { nilai t pada tabel }(5 \% \text { dan nilai derajat bebas galat }) . \\
\mathrm{KT} \text { galat } & =\text { nilai kuadrat tengah galat. } \\
\mathrm{t} & =\text { jumlah perlakuan } \\
\mathrm{r} & =\text { jumlah ulangan }
\end{array}
$$

\section{HASIL PENELITIAN DAN PEMBAHASAN}

\subsection{Tinggi Tanaman}

Tinggi tanaman pada umur 2 minggu setelah tanam

Hasil sidik ragam menunjukkan bahwa perlakuan pupuk NPK Mutiara (M) dan Plant Catalyst (P) berpengaruh sangat nyata, dan interaksinya $(\mathrm{M} \times \mathrm{P})$ berpengaruh nyata terhadap tinggi tanaman pada umur 2 minggu setelah tanam.

Hasil penelitian pengaruh pupuk NPK Mutiara dan pupuk Plant Catalyst serta interaksinya terhadap rata-rata tinggi tanaman cabai keriting pada umur 2 minggu setelah tanam.

Hasil uji BNT 5\% pengaruh pupuk NPK Mutiara (M) terhadap rata-rata tinggi tanaman pada umur 2 minggu hari setelah tanam menunjukkan perlakuan 1,5 $\mathrm{g}$ polibag $^{-1}(\mathrm{~m} 2)$ dan $2 \mathrm{~g}_{\text {polibag }}{ }^{-1}$ (m3) berbeda nyata dibandingkan dengan perlakuan tanpa pupuk NPK Mutiara (m0) dan $1 \mathrm{~g}$ polibag $^{-1}$ (m1), tetapi diantara kedua perlakuan (m2 dan $\mathrm{m} 3$ ) tersebut berbeda tidak nyata. Perlakuan 1 $\mathrm{g}_{\text {polibag }}{ }^{-1}$ (m1) berbeda tidak nyata dibandingkan dengan perlakuan tanpa pupuk NPK Mutiara (m0). Tanaman paling tinggi pada umur 2 minggu setelah tanaman dihasilkan pada perlakuan $1,5 \mathrm{~g}$ polibag $^{-1}$ (m2) dan 2 g polibag $^{-1}$ (m3) yaitu $26,70 \mathrm{~cm}$, sedangkan yang paling pendek dihasilkan pada perlakuan tanpa pupuk NPK Mutiara (m0) yaitu 23,35 $\mathrm{cm}$.

Hasil uji BNT 5\% pengaruh pupuk Plant Catalyst (P) terhadap rata-rata tinggi tanaman pada umur 2 minggu hari setelah tanam menunjukkan perlakuan 1 $\mathrm{g} \mathrm{l}^{-1}$ air (p1) dan 1,5 $\mathrm{g} \mathrm{l}^{-1}$ air (p2) berbeda nyata dibandingkan dengan perlakuan tanpa pupuk Plant Catalyst (p0) dan $2 \mathrm{~g} \mathrm{l}^{-}$ ${ }^{1}$ air (p3), tetapi diantara kedua perlakuan (p1 dan p2) tersebut berbeda tidak nyata. Perlakuan $2 \mathrm{~g} \mathrm{l}^{-1}$ air (p3) berbeda tidak nyata dibandingkan dengan perlakuan tanpa pupuk Plant Catalyst (p0). Tanaman paling tinggi pada umur 2 minggu setelah tanaman dihasilkan pada perlakuan 1,5 $\mathrm{g} \mathrm{l}^{-1}$ air (p2) yaitu 26,70 $\mathrm{cm}$, sedangkan yang paling pendek dihasilkan pada perlakuan Plant Catalyst (p0) yaitu 23,75 cm.

Hasil uji BNT 5\% pengaruh interaksi antara pupuk NPK Mutiara dan pupuk Plant Catalyst (MxP) terhadap rata-rata tinggi tanaman pada umur 2 minggu hari setelah tanam menunjukkan kombinasi $\mathrm{m} 1 \mathrm{p} 2, \mathrm{~m} 2 \mathrm{p} 1$ dan $\mathrm{m} 2 \mathrm{p} 2$ berbeda nyata dibandingkan dengan m0p0, m0p1, m0p3, m1p0, dan m1p3, tetapi berbeda tidak nyata dibandingkan dengan kombinasi $\mathrm{m} 0 \mathrm{p} 2, \mathrm{~m} 1 \mathrm{p} 1, \mathrm{~m} 2 \mathrm{p} 0$, $\mathrm{m} 2 \mathrm{p} 3, \quad \mathrm{~m} 3 \mathrm{p} 0, \quad \mathrm{~m} 3 \mathrm{p} 2$ dan $\mathrm{m} 3 \mathrm{p} 3$. Kombinasi m2p0 m3p3 berbeda nyata dibandingkan dengan m0p1, m0p3, m1p0, dan m1p3 tetapi berbeda tidak nyata dibandingkan dengan kombinasi $\mathrm{m} 0 \mathrm{p} 0, \mathrm{~m} 0 \mathrm{p} 2, \mathrm{~m} 1 \mathrm{p} 1, \mathrm{~m} 2 \mathrm{p} 3, \mathrm{~m} 3 \mathrm{p} 0$, dan $\mathrm{m} 3 \mathrm{p} 2$. Kombinasi m0p2, m1p1, m3p0 dan $\mathrm{m} 3 \mathrm{p} 2$ berbeda nyata dibandingkan dengan kombinasi m0p0, m0p3, m1p0, dan m1p3 tetapi berbeda tidak nyata dibandingkan dengan kombinasi m0p1, $\mathrm{m} 2 \mathrm{p} 3$, dan $\mathrm{m} 3 \mathrm{p} 2$. Kombinasi m2p3 berbeda nyata dibandingkan dengan m0p0, tetapi berbeda tidak nyata dibandingkan dengan kombinasi m0p1, m0p3, m1p0, dan m1p3. Kombinasi 
m0p3 berbeda nyata dibandingkan dengan $\mathrm{m} 0 \mathrm{p} 0$, tetapi berbeda tidak nyata dibandingkan dengan kombinasi m1p0, dan m1p3. Kombinasi m1p0 dan m1p3 berbeda tidak nyata dibandingkan dengan m0p0. Tanaman paling tinggi pada umur 2 minggu setelah tanaman dihasilkan pada perlakuan kombinasi m3p1 yaitu $27,80 \mathrm{~cm}$, sedangkan yang paling pendek dihasilkan pada kombinasi m0p0 yaitu 19,80 cm.

Tinggi tanaman pada umur 4 minggu setelah tanam

Hasil sidik ragam menunjukkan bahwa perlakuan pupuk NPK Mutiara (M) dan Plant Catalyst (P) serta interaksinya $(\mathrm{M} \times \mathrm{P})$ berpengaruh tidak nyata terhadap tinggi tanaman pada umur 4 minggu setelah tanam.

Hasil penelitian pengaruh pupuk NPK Mutiara dan pupuk Plant Catalyst serta interaksinya terhadap rata-rata tinggi tanaman cabai keriting pada umur 4 minggu setelah tanam.

Tinggi tanaman pada umur 6 minggu setelah tanam

Hasil sidik ragam menunjukkan bahwa perlakuan pupuk NPK Mutiara (M) berpengaruh nyata, sedangkan perlakuan pupuk Plant Catalyst (P) dan interaksinya $(\mathrm{M} \times \mathrm{P})$ berpengaruh tidak nyata terhadap tinggi tanaman pada umur 6 minggu setelah tanam.

Hasil penelitian pengaruh pupuk NPK Mutiara dan pupuk Plant Catalyst serta interaksinya terhadap rata-rata tinggi tanaman cabai keriting pada umur 6 minggu setelah tanam.

Hasil uji BNT 5\% pengaruh pupuk NPK Mutiara (M) terhadap rata-rata tinggi tanaman pada umur 6 minggu hari setelah tanam menunjukkan perlakuan 1,5 $\mathrm{g}$ polibag $^{-1}(\mathrm{~m} 2)$ dan $2 \mathrm{~g}$ polibag $^{-1}$ (m3) berbeda nyata dibandingkan dengan perlakuan $1 \mathrm{~g}$ polibag $^{-1}$ (m1), tetapi berbeda tidak nyata dibandingkan dengan perlakuan tanpa pupuk NPK Mutiara (m0). Perlakuan 1 g polibag ${ }^{-1}$ (m1) berbeda tidak nyata dibandingkan dengan perlakuan tanpa pupuk NPK Mutiara (m0). Tanaman paling tinggi pada umur 6 minggu setelah tanaman dihasilkan pada perlakuan $1,5 \mathrm{~g}^{\text {polibag }}{ }^{-1}(\mathrm{~m} 2)$ yaitu $62,75 \mathrm{~cm}$, sedangkan yang paling pendek dihasilkan pada perlakuan $1 \mathrm{~g}^{\text {polibag }}{ }^{-1}$ (m1) yaitu 53,75 cm.

\subsection{Umur Tanaman Saat Berbunga}

Hasil sidik ragam menunjukkan bahwa perlakuan pupuk NPK Mutiara (M) dan Plant Catalyst (P) serta interaksinya $(\mathrm{M} \times \mathrm{P})$ berpengaruh tidak nyata terhadap umur tanaman pada saat berbunga.

Hasil penelitian pengaruh pupuk NPK Mutiara dan pupuk Plant Catalyst serta interaksinya terhadap rata-rata umur tanaman saat berbunga.

\subsection{Umur Tanaman Saat Panen}

Hasil sidik ragam menunjukkan bahwa perlakuan pupuk NPK Mutiara (M) dan Plant Catalyst (P) serta interaksinya $(\mathrm{M} \times \mathrm{P})$ berpengaruh tidak nyata terhadap umur tanaman pada saat panen.

Hasil penelitian pengaruh pupuk NPK Mutiara dan pupuk Plant Catalyst serta interaksinya terhadap rata-rata umur tanaman saat panen.

\subsection{Jumlah Buah per Tanaman}

Hasil sidik ragam menunjukkan bahwa perlakuan pupuk NPK Mutiara (M) dan Plant Catalyst (P) serta interaksinya $(\mathrm{M} \times \mathrm{P})$ berpengaruh tidak nyata terhadap jumlah buah per tanaman.

Hasil penelitian pengaruh pupuk NPK Mutiara dan pupuk Plant Catalyst serta interaksinya terhadap rata-rata jumlah buah per tanaman.

\subsection{Berat Buah per Tanaman}


Hasil sidik ragam menunjukkan bahwa perlakuan pupuk NPK Mutiara (M) dan Plant Catalyst (P) serta interaksinya $(\mathrm{M} \times \mathrm{P})$ berpengaruh tidak nyata terhadap berat buah per tanaman.
Hasil penelitian pengaruh pupuk NPK Mutiara dan pupuk Plant Catalyst serta interaksinya terhadap rata-rata berat buah per tanaman.

Tabel 1. Rekapitulasi Hasil Penelitian Pengaruh Pupuk NPK Mutiara dan Pupuk Plant Catalyst serta Interaksinya terhadap Pertumbuhan dan Hasil Tanaman Cabai Keriting Varietas Lado F1.

\begin{tabular}{|c|c|c|c|c|c|c|c|}
\hline \multirow{2}{*}{$\begin{array}{c}\text { Faktor } \\
\text { Perlakuan }\end{array}$} & \multicolumn{3}{|c|}{ Tinggi Tanaman $(\mathrm{cm})$} & \multirow{2}{*}{$\begin{array}{c}\text { Saat } \\
\text { Berbunga } \\
\text { (hst) }\end{array}$} & \multirow{2}{*}{$\begin{array}{c}\text { Saat } \\
\text { Panen } \\
\text { (hst) }\end{array}$} & \multirow{2}{*}{$\begin{array}{c}\text { Jumlah } \\
\text { Buah } \\
\left(\text { buah } \tan ^{-1}\right)\end{array}$} & \multirow{2}{*}{$\begin{array}{c}\text { Berat } \\
\text { Buah } \\
\left(\mathrm{g} \mathrm{tan}^{-1}\right)\end{array}$} \\
\hline & $2 \mathrm{mst}$ & $4 \mathrm{mst}$ & $6 \mathrm{mst}$ & & & & \\
\hline $\begin{array}{l}\text { Pupuk NPK } \\
\text { Mutiara (M) }\end{array}$ & $* *$ & tn & $*$ & tn & tn & tn & tn \\
\hline $\begin{array}{l}0 \text { g polibag }{ }^{-1} \\
(\mathrm{~m} 0)\end{array}$ & $23,35 b$ & 46,35 & $59,10 \mathrm{ab}$ & 58,65 & 88,60 & 24,25 & 61,50 \\
\hline $\begin{array}{l}1 \mathrm{~g} \text { polibag }^{-1} \\
(\mathrm{~m} 1)\end{array}$ & $24,45 b$ & 44,20 & $53,75 b$ & 60,05 & 89,15 & 25,75 & 61,50 \\
\hline $\begin{array}{l}1,5 \text { g polibag }^{-1} \\
(\mathrm{~m} 2)\end{array}$ & $26,70 \mathrm{a}$ & 48,10 & $62,75 a$ & 59,95 & 88,40 & 29,25 & 70,75 \\
\hline $\begin{array}{l}2 \mathrm{~g} \text { polibag }^{-1} \\
(\mathrm{~m} 3)\end{array}$ & $26,70 \mathrm{a}$ & 46,60 & $59,65 \mathrm{a}$ & 59,65 & 87,55 & 35,50 & 84,00 \\
\hline $\begin{array}{l}\text { Plant Catalyst } \\
\text { (P) }\end{array}$ & $* *$ & tn & tn & tn & tn & tn & tn \\
\hline $0 \mathrm{~g} \mathrm{l}^{-1}$ air $(\mathrm{p} 0)$ & $23,75 b$ & 47,75 & 60,75 & 60,15 & 87,50 & 27,50 & 67,25 \\
\hline $1 \mathrm{~g} \mathrm{l}^{-1}$ air $(\mathrm{p} 1)$ & $27,80 \mathrm{a}$ & 43,85 & 56,50 & 58,65 & 89,30 & 29,75 & 73,25 \\
\hline$\underset{(\mathrm{p} 2)}{1,5} \mathrm{~g}^{-1^{-1}}$ air & $26,70 \mathrm{a}$ & 45,95 & 58,65 & 59,55 & 88,00 & 29,75 & 71,75 \\
\hline $2 \mathrm{~g} \mathrm{l}^{-1}$ air (p3) & $24,40 \mathrm{~b}$ & 47,70 & 59,55 & 59,75 & 88,96 & 27,75 & 65,60 \\
\hline $\begin{array}{c}\text { Interaksi } \\
(\mathrm{MxP})\end{array}$ & $*$ & tn & tn & tn & tn & tn & tn \\
\hline $\mathrm{m} 0 \mathrm{p} 0$ & $19,80 \mathrm{f}$ & 45,20 & 58,20 & 59,20 & 87,40 & 25,00 & 63,00 \\
\hline $\mathrm{m} 0 \mathrm{p} 1$ & $24,00 \mathrm{bcde}$ & 44,80 & 58,80 & 57,80 & 88,60 & 28,00 & 80,00 \\
\hline $\mathrm{m} 0 \mathrm{p} 2$ & $26,0 \mathrm{abc}$ & 47,80 & 63,80 & 59,20 & 88,00 & 23,00 & 68,00 \\
\hline $\mathrm{m} 0 \mathrm{p} 3$ & $23,80 \mathrm{de}$ & 47,80 & 55,60 & 58,40 & 89,20 & 21,00 & 82,00 \\
\hline $\mathrm{m} 1 \mathrm{p} 0$ & $22,40 \mathrm{def}$ & 45,80 & 54,40 & 60,40 & 87,40 & 24,00 & 56,00 \\
\hline m1p1 & $26,40 \mathrm{abc}$ & 47,00 & 56,60 & 54,20 & 91,40 & 24,00 & 53,00 \\
\hline $\mathrm{m} 1 \mathrm{p} 2$ & $27,20 \mathrm{a}$ & 41,20 & 49,00 & 58,60 & 88,00 & 31,00 & 77,00 \\
\hline m1p3 & $21,80 \mathrm{ef}$ & 42,80 & 55,00 & 62,00 & 89,80 & 24,00 & 60,00 \\
\hline $\mathrm{m} 2 \mathrm{p} 0$ & $27,00 \mathrm{ab}$ & 49,60 & 66,80 & 60,80 & 86,60 & 27,00 & 68,00 \\
\hline $\mathrm{m} 2 \mathrm{p} 1$ & $27,20 \mathrm{a}$ & 44,00 & 58,00 & 60,00 & 88,60 & 28,00 & 66,00 \\
\hline $\mathrm{m} 2 \mathrm{p} 2$ & $27,20 \mathrm{a}$ & 48,40 & 62,40 & 60,60 & 90,40 & 31,00 & 75,00 \\
\hline $\mathrm{m} 2 \mathrm{p} 3$ & $25,40 \mathrm{abcd}$ & 50,40 & 63,80 & 58,40 & 88,00 & 31,00 & 74,00 \\
\hline $\mathrm{m} 3 \mathrm{p} 0$ & $25,80 \mathrm{abc}$ & 50,40 & 63,60 & 60,20 & 87,40 & 34,00 & 82,00 \\
\hline $\mathrm{m} 3 \mathrm{p} 1$ & $27,80 \mathrm{a}$ & 39,60 & 52,60 & 58,40 & 88,60 & 39,00 & 94,00 \\
\hline $\mathrm{m} 3 \mathrm{p} 2$ & $26,40 \mathrm{abc}$ & 46,40 & 59,40 & 59,80 & 85,60 & 34,00 & 83,00 \\
\hline $\mathrm{m} 3 \mathrm{p} 3$ & $26,80 \mathrm{ab}$ & 50,00 & 63,80 & 60,20 & 88,60 & 35,00 & 77,00 \\
\hline
\end{tabular}

Keterangan :

- Angka rata-rata yang diikuti dengan huruf kecil yang sama berarti berbeda tidak nyata berdasarkan hasil uji BNT para taraf $5 \%$.

- $\quad$ tn = berpengaruh tidak nyata; $*$ = berpengaruh nyata; $* *=$ berpengaruh sangat nyata;

- $\quad$ hst $=$ hari setelah tanam, dan mst $=$ minggu setelah tanam

Berdasarkan data hasil analisis tanah menunjukkan bahwa keadaan tanah bereaksi sangat masam, kandungan unsur hara $\mathrm{N}, \mathrm{P}$, dan $\mathrm{K}$ tergolong sangat rendah 
sampai rendah, kation basa $\mathrm{Ca}^{++}, \mathrm{Mg}^{++}$, $\mathrm{K}^{+}$, dan $\mathrm{Na}^{+}$, kapasitas tukar kation dan kejenuhan basa semuanya tergolong rendah.

Pengaruh Pupuk NPK Mutiara terhadap Pertumbuhan dan Hasil Tanaman Cabai Keriting. Hasil sidik ragam menunjukkan bahwa perlakuan pupuk NPK Mutiara berpengaruh sangat nyata terhadap tinggi tanaman pada umur 2 minggu setelah tanam; berpengaruh tidak nyata terhadap tinggi tanaman pada umur 4 minggu setelah tanam, dan berpengaruh nyata terhadap tinggi tanaman pada umur 6 minggu setelah tanam. Hasil penelitian menunjukkan bahwa pemberian pupuk NPK Mutiara dengan dosis $1,5 \mathrm{~g}$ polibag $^{-1}$ (m2) menghasilkan tanaman paling tinggi, disusul perlakuan $2 \mathrm{~g}_{\text {polibag }}^{-1}$ (m3), perlakuan tanpa pupuk NPK Mutiara (m0) dan yang paling rendah dihasilkan pada perlakuan $1 \mathrm{~g}$ polibag $^{-1}$ (m1). Secara umum hasil penelitian pengaruh pupuk NPK Mutiara terhadap tinggi tanaman cabai keriting pada umur 2, 4 dan 6 minggu setelah tanam adalah lebih rendah dibandingkan dengan deskripsi tinggi tanaman cabai kering varietas Lado F1 yang berkisar antara $90-100 \mathrm{~cm}$. Keadaan ini disebabkan karena sifat kimia media tanam yang digunakan berdasarkan hasil analisis tanah di laboratorium berkisar sangat rendah sampai rendah dan tanah bereaksi sangat masam dengan $\mathrm{pH}=4,56$. Meskipun telah dilakukan pemberian berbagai dosis pupuk NPK Mutiara namun pertumbuhan tinggi tanaman cabai keriting masih belum mampu mencapai tinggi tanaman seperti dalam keadaan kondisi unsur hara tercukupi.Seperti dinyatakan oleh Prihmantoro (2003) bahwa efektivitas pemberian pupuk sangat tergantung pada saat diberikan, pemberian pupuk yang tidak tepat akan terbuang percuma atau tidak sesuai dengan kebutuhan tanaman pada saat itu.
Hasil sidik ragam menunjukkan bahwa perlakuan pupuk NPK Mutiara berpengaruh tidak nyata terhadap umur tanaman saat berbunga dan umur tanaman saat panen. Hasil penelitian menunjukkan bahwa rata-rata umur tanaman saat berbunga adalah 58,65 60,05 hari setelah tanam dan rata-rata umur tanaman saat panen adalah 87,55 89,15 hari setelah tanam. Hasil penelitian tersebut tidak berbeda jauh dengan deskripsi varietas Lado F1 yaitu umur saat berbunga antara 70 hari setelah sebar dan umur panen $105-120$ hari setelah sebar. Tidak adanya perbedaan tersebut disebabkan karena untuk proses pembungaan dan pemasakan buah selain dipengaruhi oleh faktor lingkungan (tanah dan iklim) juga dipengaruhi oleh faktor dalam itu sendiri.

Hasil sidik ragam menunjukkan bahwa perlakuan pupuk NPK Mutiara berpengaruh tidak nyata terhadap jumlah buah tanaman dan berat buah per tanaman. Hasil penelitian menunjukkan bahwa pemberian berbagai pupuk NPK Mutiara (1 $\mathrm{g}_{\text {polibag }}{ }^{-1}, 1,5 \mathrm{~g}_{\text {polibag }}{ }^{-1}$, dan $2 \quad \mathrm{~g} \quad$ polibag $\left.^{-1}\right)$ cenderung menghasilkan jumlah buah per tanaman yang lebih banyak yaitu berturut-turut 25,75 ; 29,25; dan 35,50 buah per tanaman; dan berat buah per tanaman yang lebih tinggi yaitu berturut-turut 61,60; 70,75; dan 84,00 g per tanaman; sedangkan perlakuan tanpa pupuk NPK Mutiara (m0) hanya menghasilkan 24,25 buah per tanaman dan $61,50 \mathrm{~g}$ per tanaman.Secara umum hasil penelitian terhadap jumlah dan berat buah tanaman cabai keriting per tanaman adalah lebih rendah dibandingkan dengan deskripsi hasil buah cabai keriting varietas Lado F1 yang mencapai $1 \mathrm{~kg}$ per tanaman. Keadaan ini disebabkan karena tingkat kesuburan media tanam yang digunakan tergolong rendah dan pemberian berbagai dosispupuk NPK Mutiara belum mampu memenuhi kebutuhan unsur hara tanaman 
cabai keriting, sehingga hasil buah tanaman tidak meningkat secara nyata. Seperti dikemukakan oleh Mulyani Sutejo dan Kartasapoetra (2003) bahwa sesuai dengan kegiatan proses fisiologis pertumbuhan dan perkembangannya, tanaman memerlukan unsur hara yang cukup, sehingga pemupukan harus sesuai dengan kebutuhan tanaman.

Pengaruh Pupuk Plant Catalyst terhadap Pertumbuhan dan Hasil Tanaman Cabai Keriting. Hasil sidik ragam menunjukkan bahwa perlakuan pupuk Plant Catalyst berpengaruh nyata terhadap tinggi tanaman pada umur 2 minggu setelah tanam. Hasil penelitian yang disajikan pada Tabel 10 memperlihatkan bahwa pemberian berbagai konsentrasi pupuk Plant Catalyst ( $1 \mathrm{~g} \mathrm{l}^{-1}$ air; $1,5 \mathrm{~g} \mathrm{l}^{-1}$ air; dan $2 \mathrm{~g} \mathrm{l}^{-}$ 1 air) menghasilkan tanaman cabai keriting yang lebih tinggi dibandingkan dengan perlakuan tanpa pupuk Plant Catalyst (p0). Hal ini disebabkan karena kandungan unsur hara $\mathrm{N}$ dalam media tanam yang tergolong rendah yaitu hanya $0,18 \%$, dengan pemberian pupuk Plant Catalyst dapat meningkatkan serapan unsur hara $\mathrm{N}$ oleh tanaman cabai keriting, dan selanjutnya dapat mendorong pertumbuhan tinggi tanaman. Seperti dikemukakan oleh Munawar (2011) bahwa selain untuk pembentukan protein, unsur $\mathrm{N}$ merupakan penyusun klorofil yang sangat diperlukan untuk proses fotosintesis. Kecukupan pasokan unsur $\mathrm{N}$ bagi tanaman dapat meningkatkan aktivitas fotosintesis dalam tanaman dan mendorong/memacu pertumbuhan vegetatif yang baik.

Hasil sidik ragam menunjukkan bahwa perlakuan pupuk Plant Catalyst berpengaruh tidak nyata terhadap tinggi tanaman pada umur 4 dan 6 minggu setelah tanam. Tidak adanya pengaruh yang nyata dari pemberian berbagai konsentrasi pupuk Plant Catalyst tersebut disebabkan dengan bertambahnya umur tanaman cabai keriting, maka kebutuhan tanaman akan unsur hara juga semakin bertambah banyak, di sisi lain ketersediaan unsur hara dalam media tanam yang rendah dan semakin berkurang karena diabsorbsi oleh tanaman dan unsur hara yang ditambahkan melalui pemberian pupuk Plant Catalyst belum mencukupi, sehingga pengaruhnya tidak terlihat nyata. Seperti dikemukakan oleh Winarso (2005) bahwa penggunaan pupuk akan menguntungkan apabila memperhatikan 5 tepat, yaitu tepat macam/jenis pupuk, tepat dosis/konsentrasi, tepat tempat pemupukan, tepat waktu dan tepat cara/metode pemupukan. Ketidaktepatan salah satu dari 5 tepat tersebut maka akan ditunjukkan hasil pemupukan yang kurang efisien.

Hasil sidik ragam menunjukkan bahwa perlakuan pupuk Plant Catalyst berpengaruh tidak nyata terhadap umur tanaman saat berbunga dan umur tanaman saat panen. Hasil penelitian memperlihatkan bahwa umur tanaman saat berbunga berkisar antara 58,65 60,15 hari setelah tanam dan umur tanaman saat panen berkisar antara 87,50 - 89,30 hari setelah tanam. Hasil penelitian tersebut tidak berbeda jauh dengan deskripsi varietas Lado F1 yaitu umur saat berbunga antara 70 hari setelah sebar dan umur panen 105 - 120 hari setelah sebar. Keadaan ini disebabkan karena proses pembungaan dan pemasakan tersebut selain ditentukan oleh faktor lingkungan /faktor luar juga ditentukan oleh faktor dalam tanaman itu sendiri. Seperti dinyatakan oleh Lakitan (1996) bahwa perubahan tunas vegetatif ke tunas generatif merupakan perubahan besar yang merupakan cerminan dari pemacuan kelompok gen-gen tertentu yang berperan dalam pembentukan bunga dan penghambatan terhadap kelompok gen-gen lainnya yang berperan dalam perkembangan organ vegetatif. Proses 
tersebut dipengaruhi oleh faktor eksternal/luar dan faktor internal/dalam tanaman itu sendiri. Selain itu juga dapat disebabkan karena unsur hara fosfor $(\mathrm{P})$ dalam media tanam hanya sebesar 0,55 ppm yang tergolong sangat rendah dan unsur $\mathrm{P}$ yang ditambahkan melalui pemberian pupuk Plant Catalyst belum mampu memenuhi kebutuhan unsur hara $P$ yang sangat dibutuhkan untuk proses pembungaan dan pemasakan buah.

Hasil sidik ragam menunjukkan bahwa perlakuan pupuk Plant Catalyst berpengaruh tidak nyata terhadap jumlah buah per tanaman dan berat buah per tanaman. Hasil penelitian menunjukkan bahwa pemberian berbagai konsentrasi pupuk Plant Catalyst $\left(1 \mathrm{~g}^{-1}\right.$ air; $1,5 \mathrm{~g} 1$ -1 air) cenderung menghasilkan jumlah buah per tanaman yang lebih banyak yaitu 29,75 buah per tanaman; dan berat buah per tanaman yang lebih tinggi yaitu berturut-turut 73,25 ; dan $71,75 \mathrm{~g}$ per tanaman; sedangkan perlakuan tanpa pupuk Plant Catalyst (p0) hanya menghasilkan 27,50 buah per tanaman dan $67,25 \mathrm{~g}$ per tanaman. Secara umum hasil penelitian terhadap buah tanaman cabai keriting adalah lebih rendah dibandingkan dengan deskripsi hasil buah cabai keriting varietas Lado F1 yang mencapai $1 \mathrm{~kg}$ tanaman $^{-1}$. Keadaan ini disebabkan karena ketersediaan unsur hara dalam media tanam yang rendah dan unsur hara yang ditambahkan melalui pemberian pupuk Plant Catalyst belum mampu memenuhi kebutuhan pertumbuhan dan perkembangan tanaman cabai keriting, sehingga tanaman tidak dapat memberikan hasil buah yang baik dan tinggi. Seperti dinyatakan oleh Dwidjoseputro (1998), bahwa tanaman akan tumbuh subur dan memberikan hasil yang baik jika unsur hara yang dibutuhkannya tersedia dalam jumlah cukup dan seimbang.

Pengaruh Interaksi antara Pupuk NPK Mutiara dan Pupuk Plant Catalyst terhadap Pertumbuhan dan Hasil Tanaman Cabai Keriting. Hasil sidik ragam menunjukkan bahwa interaksi antara faktor dosis pupuk NPK Mutiara dan faktor konsentrasi pupuk Plant Catalyst berpengaruh tidak nyata terhadap tinggi tanaman pada umur 4 dan 6minggu setelah tanam, umur tanaman saat berbunga, umur tanaman saat panen, jumlah buah per tanaman, dan berat buah per tanaman; tetapi berpengaruh nyata terhadap tinggi tanaman umur 2 minggu setelah tanam. Keadaan ini menunjukkan bahwa antara faktor dosis pupuk NPK Mutiara dan faktor konsentrasi pupuk Plant Catalyst dapat secara bersama-sama ataupun tidak secara bersama-sama dalam mempengaruhi pertumbuhan dan hasil tanaman cabai keriting. Seperti dikemukakan oleh Steel dan Torrie (1991), bahwa apabila pengaruh interaksi berbeda tidak nyata maka disimpulkan bahwa diantara faktor perlakuan tersebut bertindak bebas satu sama lainnya. Selanjutnya dinyatakan oleh Gomez dan Gomez (1995), bahwa dua faktor dikatakan berinteraksi apabila pengaruh suatu faktor perlakuan berubah pada saat perubahan taraf faktor perlakuan lainnya.

Secara umum hasil penelitian yang disajikan pada Tabel 1 (rekapitulasi hasil penelitian) menunjukkan bahwa perlakuan kombinasi antara berbagai dosis pupuk NPK Mutiara dan konsentrasi pupuk Plant Catalyst menghasilkan pertumbuhan tinggi tanaman dan hasil buah per tanaman yang lebih rendah dibandingkan dengan tinggi tanaman dan hasil buah menurut deskripsi. Keadaan ini disebabkan karena tingkat kesuburan media tanam yang rendah dan pemberian unsur hara dari kedua jenis pupuk tersebut belum mampu mencukupi kebutuhan untuk pertumbuhan dan hasil tanaman cabai keriting dan cuaca panas. 


\section{KESIMPULAN}

Berdasarkan hasil penelitian dan pembahasan dapat disimpulkan yaitu sebagai berikut : Perlakuan pupuk NPK Mutiara berpengaruh sangat nyata dan nyata terhadap tinggi tanaman pada umur 2 dan 6 minggu setelah tanam, tetapi berpengaruh tidak nyata terhadap tinggi tanaman pada umur 4 minggu setelah tanam, umur tanaman saat berbunga, umur tanaman saat panen, jumlah buah dan berat buah per tanaman.

Perlakuan pupuk Plant Catalyst berpengaruh sangat nyata terhadap tinggi tanaman pada umur 2 minggu setelah tanam, tetapi berpengaruh tidak nyata tinggi tanaman pada umur 4 dan 6 minggu setelah tanam, umur tanaman saat berbunga, umur tanaman saat panen, jumlah buah dan berat buah per tanaman.

Interaksi antara perlakuan dosis pupuk NPK Mutiara dan perlakuan konsentrasi pupuk Plant Catalyst berpengaruh nyata terhadap tinggi tanaman pada umur 2 minggu setelah tanam, tetapi berpengaruh tidak nyata tinggi tanaman pada umur 4 dan 6 minggu setelah tanam, umur tanaman saat berbunga, umur tanaman saat panen, jumlah buah dan berat buah per tanaman.

Pemberian pupuk NPK Mutiara dengan dosis $2 \mathrm{~g}$ polibag $^{-1}$ dan pupuk Plant Catalyst $1 \mathrm{~g} \mathrm{l}^{-1}$ air cenderung menghasilkan berat buah per tanaman yang paling tinggi yaitu $94.00 \mathrm{~g}$ tanaman

\section{DAFTAR PUSTAKA}

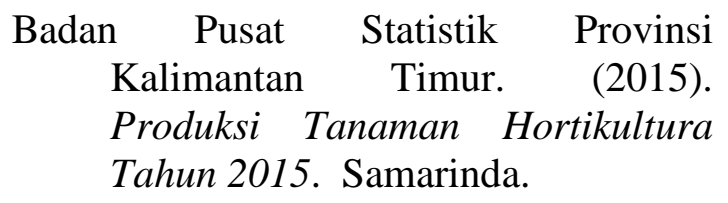

CNI. (2011). Plant Catalyst 2006, Meningkatkan Produktivitas Tanaman. Diakses 8 Maret 2018, dari https://www.cni.co.id/index.php/pr oducts-

info/productcategory/productscategories/farming/2-plant-catalyst2006- meningkatkan-produktivitastanaman.html.

Dwidjoseputro, D. (1998). Pengantar Fisiologi Tumbuhan. Jakarta: Gramedia.

Gomez, K.A dan A.A. Gomez . (1995). Prosedur Statistik untuk Penelitian Pertanian Terjemahan A. Sjamsuddin dan J.S Baharsyah). Edisi Kedua. Jakarta: UI Press.

Lakitan, B.(1996). Dasar-dasar Fisiologi Tumbuhan. Jakarta: PT Raja Grafindo persada.

Lingga, P dan Marsono. (2013). Petunjuk penggunaan Pupuk. Jakarta: Penebar Swadaya.

Mulyani Sutejo, M. dan A.G. Kartasapoetra. (2003). Pupuk dan Cara Pemupukan. Jakarta: Rineka Cipta.

Munawar, A. (2011). Kesuburan Tanah dan Nutrisi Tanaman. Bogor: IPB Press.

Novizan. (2007). Petunjuk Pemupukan Yang Efektif. Jakarta: Agro Media Pustaka.

Prihmantoro, H. (2003). Memupuk Tanaman Sayuran. Jakarta: Penebar Swadaya.

Steel, R.G.D dan J. H. Torrie. (1991). Prinsip dan Prosedur Statistika Suatu Pendekatan Biometrik. Jakarta: Gramedia Pustaka Utama.

Winarso, S. (2005). Kesuburan Tanah, Dasar Kesehatan dan Kualitas Tanah. Yogyakarta: Gava Media. 